MARCIN GAŁKOWSKI*

Politechnika Opolska

PATRYCJA ANTOSZ**

Uniwersytet Jagielloński

DOI: $10.26485 / \mathrm{PS} / 2018 / 67.1 / 6$

\title{
MIEJSKIE PRZESTRZENIE WE WLADANIU PRYWATNYM (HYBRYDOWE PRZESTRZENIE PUBLICZNE) I ICH FUNKCJE W MIEŚCIE
}

\section{Streszczenie}

Celem artykułu jest ukazanie specyfiki hybrydowych przestrzeni miejskich. Zwiększenie się liczby takich obszarów ma bezpośredni związek ze stopniowym wzrostem dominacji modelu relacji społecznych opartych na konsumpcji [Bauman 2006; Ritzer 2001]. W wyniku tych zmian przestrzeń miejska, w tym otwarte przestrzenie piesze, zmieniają się w towar wykorzystywany do pomnażania i gromadzenia kapitału. Zmiana ta prowadzi do powstawania nowego typu przestrzeni miejskich, stanowiących konglomerat elementów charakterystycznych dla przestrzeni prywatnych i publicznych. To właśnie takie obszary wielu autorów nazywa hybrydowymi [Kohn 2004; Nissen 2008]. W dalszym ciagu mogą być one wykorzystywane jako miejsca rozrywki i socjalizacji, jednak komodyfikacja mocno zmienia ich funkcje w porównaniu z tradycyjnie rozumianą przestrzenią publiczną. Efektem jest tworzenie obszarów miasta zdominowanych wyłącznie przez rozrywkę, których użytkownicy są segregowani, a scenariusz podejmowanych na nich działań jest z góry określony. Co więcej, dochodzi tam do ograniczenia aktywności obywatelskich [Harvey 2012; Kohn 2004; Lofland 2007; Low, Smith 2006; Mitchell 2003; Sorkin, 1992]. Skomodyfikowana przestrzeń nie wspiera bowiem głębszych funkcji społecznych, takich jak: niesymulowane spotkania

* Dr inż. arch., Wydział Budownictwa i Architektury; e-mail: m.galkowski@po.opole.pl

** Dr, Instytut Socjologii; e-mail: patrycja.antosz@uj.edu.pl 
z ,innymi” i „obcymi”, publiczne zgromadzenia i pikiety czy obywatelskie protesty. Utowarowieniu towarzyszy też homogenizacja przestrzeni śródmiejskich, zarówno w warstwie wizualnej, jak i funkcjonalnej. Wspomniane ograniczenia oraz redukcja fizycznego dostępu do hybrydowych obszarów miejskich mogą stać się źródłem poważnych konfliktów społecznych.

By lepiej zidentyfikować powyższe zagadnienia, w prezentowanym tekście dokładniej omówiono przykład Centrum Handlowego „Manufaktura” w Łodzi. Centralne miejsce tego złożonego kompleksu zajmuje plac, który (według niektórych źródeł) jest największym prywatnym placem miejskim w Europie. Analiza hybrydowej natury tej przestrzeni jasno pokazuje również brak skutecznej metodologii pozwalającej na systemowy opis i porównywanie przestrzeni miejskich w warstwie ich społecznej użyteczności. Autorzy starają się wypełnić istniejącą lukę, proponując podejście mieszane.

Słowa kluczowe: miasto, przestrzeń publiczna, prywatyzacja przestrzeni miejskiej, komodyfikacja, prawo do miasta, funkcje przestrzeni publicznej, przemiany przestrzeni miejskiej, przestrzenie hybrydowe

\section{WSTĘP}

Dominacja konsumpcyjnego stylu życia w ciagu minionych dwudziestu lat zmieniła funkcję śródmieść. Coraz rzadziej przychodzimy tam na zakupy (po które jeździmy samochodem do wyspecjalizowanego obiektu galerii handlowej), za to regularnie odwiedzamy je w poszukiwaniu rozrywki i odpoczynku. Sklepy w obszarach śródmiejskich powoli ustępują miejsca usługom - głównie barom, restauracjom i klubom. Staliśmy się nowymi miejskimi flâneurami, którzy spacerując po mieście, kosztując przysmaków kulinarnych, czerpiąc z przyjemności kulturalnych czy estetycznych, spotykają podobnych sobie ludzi, by omówić nowe miejsca i smaki. Przestrzeń staje się oczyszczonym i kontrolowanym parkiem rozrywki dla dorosłych - jest ,pacyfikowana przez cappuccino”, jak pisała Sharon Zukin [1996]. Ten trend estetyzacji przestrzeni popularyzuje między innymi duński urbanista i znawca przestrzeni publicznej, Jan Gehl [Gehl 2010; Gehl \& Gemzøe 2004; Gehl i in. 2006], który w swych publikacjach opisuje metodologię tworzenia obszarów spotkań i miejskiej socjalizacji poprzez odpowiednie ukształtowanie, wyposażenie i skomponowanie elementów przestrzennych. Tymczasem w dyskursie o przestrzeni publicznej bardzo mało mówi się o innych funkcjach otwartych przestrzeni miejskich, choć oczywiste jest, że stanowią one pole do dużo szerszej ludzkiej aktywności niż tylko rekreacja i rozrywka. 


\section{WPROWADZENIE - ZOBACZYĆ UKRYTE ZMIANY}

Mało zauważalna dla użytkowników jest komodyfikacja przestrzeni miejskiej, czyli traktowanie otwartych obszarów miasta jako towaru. Jak pisze Mark Gottdiener [2000: 266]:

„[...] dziś przestrzeń zamieszkana jest zasobem zamienionym na towar (ang. commodity) przez ekonomię polityczną współczesnego kapitalizmu, który może kupować, sprzedawać, wynajmować, konstruować, burzyć, wykorzystywać i wykorzystywać wtórnie w taki sam sposób jak każdy inny rodzaj inwestycji”.

Inwestorzy rozumieją więc miasto tak samo, jak rozumieją każdy inny przedmiot, w ramach którego możliwa jest spekulacja: wycena wszystkich wartości w pieniądzu, a pominięcie tego, czego wycenić się nie da ${ }^{1}$. W takim ujęciu miasto staje się niczym więcej niż zestawem pól inwestycyjnych o różnych stopach zwrotu. Dotyczy to - pośrednio i bezpośrednio - także placów, ulic, parków, a więc tych przestrzeni, które potocznie nazywamy publicznymi. Trzeba zrozumieć, że inwestorzy widzą w otwartych, pieszych przestrzeniach nie tylko potencjalne działki inwestycyjne (co jest oczywiste), ale coraz częściej wykorzystują miejskie place czy parki do wsparcia handlu lub (co trudniej zauważyć) podniesienia wartości otaczających je nieruchomości. To zjawisko nie zostało jak dotąd szeroko opisane w literaturze, jednak można odnaleźć precyzyjne dane, na przykład przygotowane przez CBRE, dotyczące parków w Nowym Jorku². Pokazują one, że bliskość rekreacyjnej przestrzeni publicznej podnosi wartość czynszu sąsiadujących nieruchomości o średnio 44\%, a co za tym idzie - wartość samych nieruchomości.

Jednak aby obszary miejskie wspomagały pomnażanie kapitału czy wzrost wartości nieruchomości, muszą być kontrolowane i tak przestrzennie zorganizowane, by realizować określony scenariusz działań. Kontrola ta powoduje zubożenie funkcjonalne otwartych przestrzeni miejskich i eliminację wielu aktywności związanych choćby z uprawianiem polityki czy społecznym protestem ${ }^{3}$. Ograniczeniom

1 Termin „komodyfikacja” pozwala bardziej precyzyjnie opisać to zjawisko niż używany często termin ,,prywatyzacja” oznaczający wyłącznie zmianę stosunków własnościowych (np. przejście gruntów miejskich w prywatne ręce). Ten pierwszy opisuje szerzej traktowanie przestrzeni miejskiej jako towaru, który umożliwia osiagniecie (pośrednio lub bezpośrednio) korzyści biznesowych, do czego nie zawsze jest konieczna zmiana własnościowa.

2 Raport CBRE Premiums on the Parks został przygotowany w 2012 roku i można go znaleźć pod adresem: https://pl.scribd.com/document/104343327/Premiums-on-the-Park-FINAL [dostęp: 30.11.2017].

3 Lyn Lofland [Lofland 2007] wyróżnia sześć podstawowych funkcji użytkowych miejskiej przestrzeni publicznej. Są to funkcje: 1. środowiska uczącego, 2. wytchnienia i odpoczynku, 3. centrów komunikacji, 4. praktykowania polityki, 5. wyrażania społecznego porządku oraz konfliktu, 6. kreowania kosmopolitów. Te zdefiniowane funkcje prawdziwej miejskiej przestrzeni publicznej 
funkcjonalności towarzyszy często fizyczne zmniejszanie dostępu, na przykład celowe wykluczanie konkretnych grup mieszkańców miasta. Zjawiska przedmiotowe występują w śródmieściach, gdzie przyjmują postać komodyfikacji i tak zwanej cichej prywatyzacji przestrzeni publicznych (ang. shadow privatization) [Lofland 2007: 211], ale też na przedmieściach, na terenach zamkniętych osiedli, gdzie często przestrzenie wspólne należą do korporacji lub są przez nie zarządzane. Pozwalając sobie na uogólnienie, można przyjąć, że to właśnie kontrola wraz z ograniczaniem dostępu i swobód obywatelskich w przestrzeni miejskiej jest głównym zarzewiem napięć i konfliktów we współczesnych metropoliach. Najbardziej nagłośnione przez media przykłady to obrona Parku Gezi w Istambule w 2013 roku i konflikt wokół Zuccotti Plaza w Nowym Jorku ${ }^{4}$ w 2011 roku.

W krajach zachodnich, zwłaszcza w USA, temat tzw. privately-owned public spaces (POPS - przestrzenie publiczne we władaniu prywatnym) jest znany i dyskutowany. Wynika to z dużej proliferacji POPS-ów w miastach amerykańskich. W USA stworzono też ramy prawne na potrzeby takich działań w postaci Buisness Improvment Districts (BID). Jednym z najlepiej opisanych przykładów ${ }^{5}$ przejęcia miejskiej przestrzeni publicznej przez prywatny kapitał z pomocą mechanizmów opartych na BID jest Bryant Park w Nowym Jorku. Ta historyczna przestrzeń publiczna $^{6}$, po okresie degradacji w latach 70. ubiegłego wieku, została przejęta w 1980 roku przez Bryant Park Restoration Corporation (BPRC) - organizację pozarządowa, której celem była rewitalizacja i zarządzanie parkiem. BPRC przeprowadziła kompleksowy remont i rewitalizację parku. Nowy Bryant Park stał się modny i bardzo licznie uczęszczany. W 2000 roku w godzinach szczytu w parku przebywało ponad 4000 użytkowników, czyli cztery razy więcej niż w latach 70 . Jednak w tym procesie przestrzeń Bryant Park została poddana kontroli, a jej użyt-

mogą posłużyć także do jej wartościowania - obszary sprywatyzowane czy skomodyfikowane zwykle są ułomne pod względem pełnionych funkcji.

4 Problemowi dostępu do przestrzeni Zuccotti Plaza poświęcono antologię tekstów pt. Beyond Zuccotti Park. Freedom of Assembly and Occupation of Public Space [Shiffman, 2012), która porusza w szerszym ujęciu zagadnienie praw dostępu do przestrzeni oraz wolności zgromadzeń.

5 Przemianom obszaru Bryant Park poświęcono artykuły [Murray 2010], monografię [Francis 2003], występuje także jako przykład w wielu publikacjach [por. Carmona i in. 2008: 34; Zukin 1996: 111].

6 Historia tej otwartej miejskiej przestrzeni sięga XVII wieku, kiedy obszar ten został urzędowo wyznaczony jako publiczny (common ground). W latach 1839-1842 zrealizowano na tym terenie budowę rezerwuaru wodnego na potrzeby miasta (Croton Reservoir). Wokół rosła też coraz bardziej zwarta zabudowa Manhattanu. W 1884 roku Reservoir Square otrzymał swą dzisiejszą nazwę - Bryant Park, zaś w 1934 roku przebudowano park w oparciu o klasyczny projekt autorstwa architekta Lusby'ego Simpsona, z dużym otwartym trawnikiem położonym centralnie oraz reprezentacyjnymi alejami platanów wokół. 
kownicy precyzyjnej segregacji. Ograniczono dostęp bezdomnym, a użytkowanie przestrzeni wpisano w ścisłe ramy prywatnego regulaminu, określającego nawet takie szczegóły, jak sposób zbierania surowców wtórnych [Murray 2010]. Zabrania się ponadto spożywania alkoholu czy spania na parkowych ławkach. Park jest zamykany na noc, a dostępu do niego bronią prywatni ochroniarze. Bryant Park to przykład cichego modelu prywatyzacji przestrzeni publicznej. Proliferacja Business Improvement Districts jest bardzo dobrze widoczna w całym Nowym Jorku (i szerzej - w całym USA). Warto podkreślić, że BID tworzą właściciele nieruchomości i okolicznych firm, którzy wnoszą - poprzez dobrowolne opodatkowanie - kapitał i mają prawo decydowania o kierunku zmian w zarządzanej przez BID przestrzeni. Co ważne, decydujący głos w BID mają sponsorzy, a nie mieszkańcy tego obszaru czy jego użytkownicy. Takie korporacje, zarządzane przez grupy osób reprezentujące interesy prywatnego kapitału, dyskretnie przejęły kontrolę nad wieloma parkami i placami miast w USA i Europie, w tym nad tymi najbardziej znanymi, jak Central Park i Times Square w Nowym Jorku czy Oxford Street i bulwarami nad Tamizą w Londynie.

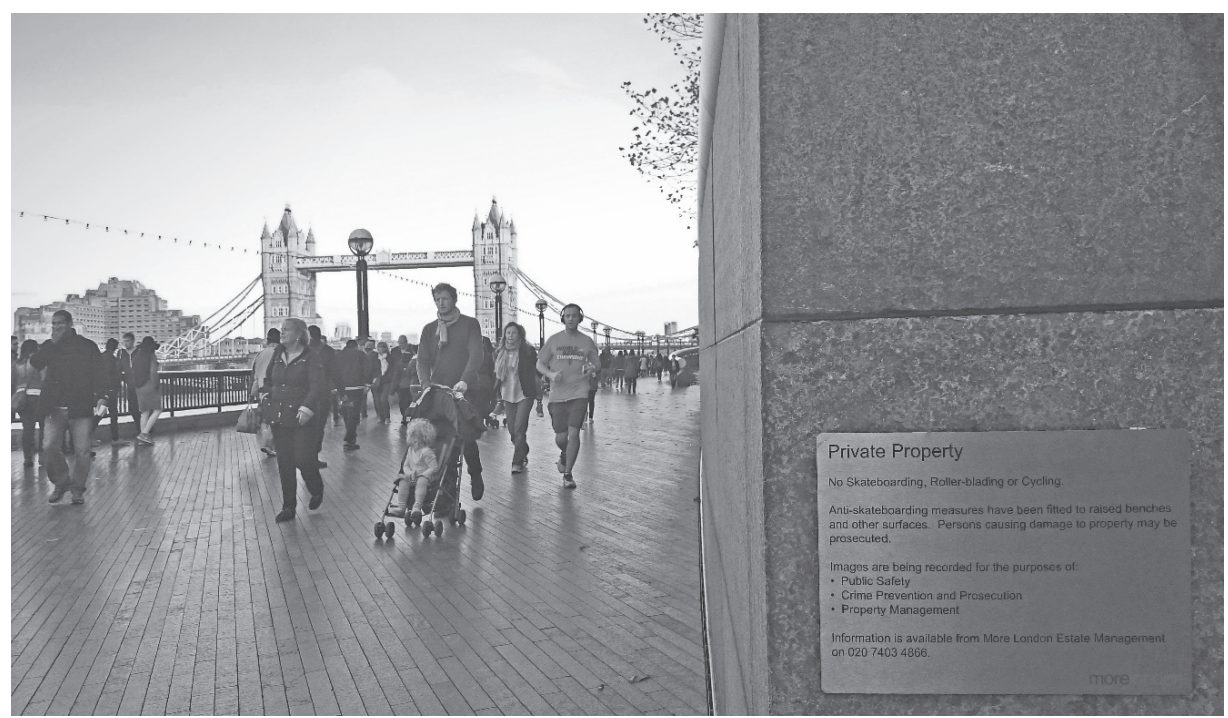

Fot. M. Gałkowski.

Zdjęcie 1. Prywatnie zarządzane bulwary w okolicach Tower Bridge. Widoczna jest tablica z wyciagiem z regulaminu, który zabrania, m.in. jazdy na deskach, rowerach czy wrotkach. Uprzedza też o stałym monitoringu (rejestrowaniu obrazów przez prywatne siły ochrony). 
W polskim dyskursie temat prywatyzacji przestrzeni publicznej pojawia się marginalnie i dotyczy raczej osiedli grodzonych [Gądecki 2009] niż otwartych placów i parków miejskich. Tymczasem liczba pozostających w prywatnych rękach placów i parków stale wzrasta; najnowszym przykładem jest choćby tzw. plac Europy w Warszawie.

Niniejszy artykuł ma na celu zwrócenie uwagi na mechanizmy komodyfikacji i prywatyzacji śródmiejskiej przestrzeni publicznej. W dalszej części zjawisko to zostanie opisane na przykładzie Rynku w Centrum Handlowym „Manufaktura” w Łodzi - jednego z największych prywatnych placów w Europie, który jest jednocześnie bardzo charakterystyczny dla naszych warunków społeczno-gospodarczych. Rozważania zawarte w artykule wieńczy wskazanie autorskiej propozycji metody badawczej umożliwiającej kompleksowy opis funkcji i społecznego odbioru przestrzeni hybrydowych, których przykładem jest łódzka Manufaktura, oraz satysfakcjonujące porównanie różnych przestrzeni tego typu.

\section{RYNEK W CENTRUM HANDLOWYM „MANUFAKTURA”}

Łódzka Manufaktura jest jedną z największych galerii handlowych w Polsce, a także w Europie. Wraz z obiektami towarzyszącymi zajmuje około 27 hektarów terenu po przedwojennych zakładach Izraela Poznańskiego, jednego z łódzkich przedsiębiorców, który pod koniec XIX wieku zbudował w Łodzi swoje fabryki, przyczyniając się do rozwoju przemysłu tekstylnego.

Po II wojnie światowej zakład został znacjonalizowany, a na jego bazie utworzono państwowe zakłady przemysłu bawełnianego. W latach 70. ubiegłego stulecia przyjęły one nazwę „Poltex”. Zatrudniano w nich blisko 12 tys. pracowników. W czasach przełomu ustrojowego zakład nie sprostał wyzwaniom wolnego rynku. Nie udało się też wprowadzić skutecznego programu restrukturyzacji. Doprowadziło to w latach 1990-1997 do powolnego zamykania poszczególnych spółek przedsiębiorstwa.

Przełom nastapił w 1998 roku, kiedy to firma Apsys przejęła teren i rozpoczęła proces przekształcenia fabryki w centrum handlowe. Był to największy projekt rewitalizacyjny zabytkowych obiektów poprzemysłowych przeprowadzony w Polsce od czasów zmian ustrojowych. Do prac projektowych wybrano architektów z francuskiej pracowni SUD Architectes z Lyonu. W latach 1999-2002 rozpoczęto wyburzanie obiektów nieposiadających wartości historycznej, a w roku 2002, po zatwierdzeniu projektu, ruszyły szeroko zakrojone prace budowlane ${ }^{7}$. Unikalną

7 W ramach projektu odrestaurowano blisko $45000 \mathrm{~m} \mathrm{kw}$. zabytkowych ceglanych elewacji. 
przestrzeń poprzemysłowych obiektów z przełomu XIX i XX wieku architekci z SUD zaadaptowali na potrzeby kompleksu handlowo-rozrywkowego. Jedną z najważniejszych decyzji projektowych było stworzenie pomiędzy obiektami kubaturowymi dużej przestrzeni pieszej - tak zwanego Rynku Manufaktury - która w mediach często nazywana jest publiczną. Jej opisy można znaleźć na wielu stronach internetowych, na przykład w artykule „Manufaktura, czyli symbol udanej rewitalizacji”, zamieszczonym w witrynie Polskiej Izby Inżynierów Budownictwa:

W trakcie prac nad wizerunkiem Manufaktury pojawiły się niezmiernie ważne pytania: jak połączyć przeszłość z nowoczesnością i jak powiązać ze sobą przemysłowe budowle oraz galerię handlową w zachodniej części obiektu, by tworzyły spójną całość? Odpowiedź na nie znalazł Andrzej Mrowcow, polsko-francuski architekt, który postanowił stworzyć tu przestrzeń publiczną poprzez wyodrębnienie Rynku Manufaktury - nowego serca Łodzi. Stanowi on bezprecedensowy przykład ambitnego projektu użyteczności publicznej, realizowanego na prywatnym terenie. Historycznie Łódź miała już dwa rynki: pierwszy na starym mieście był założony ok. 1800 r., drugi - w dzielnicy włókienniczej, zbudowany ok. 1821 r. Nie miały one jednak wystarczającej mocy architektonicznej, by zapewnić tradycyjną funkcję rynku. Powstała więc luka, którą należało uzupełnić poprzez stworzenie miejsca handlu i spotkań mieszkańców [Rąkowska 2009].

Zrealizowany projekt zrobił na znawcach tej tematyki duże wrażenie. Historyczne, ceglane budynki fabryczne po odnowieniu tworzą unikalną scenografię dla nowo projektowanej otwartej przestrzeni. Plac ma formę wydłużonego prostokąta, pierzejami jego dłuższych boków są historyczne obiekty fabryki Poznańskiego, zaś krótszy bok zamyka szklana fasada nowego obiektu galerii handlowej. Na samym placu znajdują się również odnowione pomniejsze historyczne budynki fabryczne, co wizualnie dzieli dużą przestrzeń na funkcjonalne strefy i przywodzi na myśl prawdziwie historyczne rynki miast takich jak Kraków czy Wrocław, z budynkami Sukiennic i Ratusza.

Jak można jednak zauważyć, w przeciwieństwie do rynków miejskich centralna przestrzeń Manufaktury nie jest zwornikiem ciagów komunikacyjnych, a wręcz jest od nich izolowana przez rozciagające się za zabudowaniami otwarte parkingi i wewnętrzną sieć dróg. Przez sam plac przebiega za to wyodrębniony ciąg pieszy prowadzący od przystanków komunikacji miejskiej poprzez historyczną bramę wejściową aż do najważniejszego budynku całego kompleksu - galerii handlowej.

Prywatny właściciel nadał obiektom Manufaktury funkcje pomocnicze, dość nietypowe dla polskich centrów handlowych - działają tu, m.in. lokalne muzea, ścianka wspinaczkowa czy centrum rozrywki. W przekazanej przez Apsys zabytkowej przędzalni powstała nowa siedziba muzeum sztuki nowoczesnej „ms2”. Co znamienne, właściciel centrum handlowego w swych tekstach reklamowych 
zgłasza niekiedy sugestię, że „ms2” przynależy do kompleksu Manufaktury, pomijając fakt, że galeria jest instytucją państwową powstałą przy współudziale władz i z połączonego kapitału miejskiego oraz funduszy europejskich. O sprawie tej wspomina w swym tekście Magdalena Saryusz-Wolska [2010].

RYSUNEK 1. Plan Centrum Handlowego „Manufaktura” w Łodzi, na którym zauważalna jest izolacja przestrzeni pieszej i brak charakterystycznych dla placów miejskich naturalnych połączeń z miejskimi ciagami komunikacyjnymi

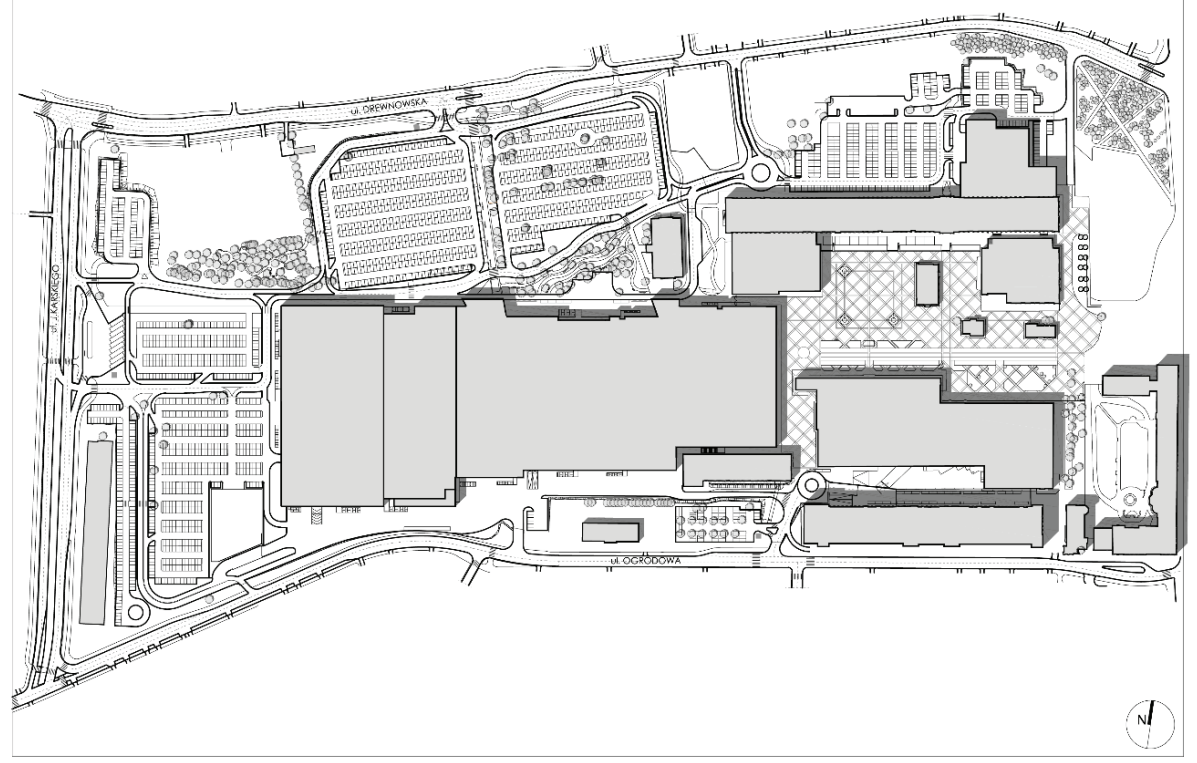

Źródło: opracowanie własne na podstawie materiałów Google Earth i prasowych [Gałkowski 2015].

Sam plac wyposażono w bardzo ciekawe, wysokiej jakości elementy małej architektury będące dalekim nawiązaniem do żeliwnych elementów z końca XIX wieku, a także elementy rzeźbiarskie, pomagające określić charakter miejsca. Dodatkową atrakcjąjest ciagg programowalnych fontann, które według informacji właściciela stanowią najdłuższy kompleks tego typu w Europie.

Fontanny stanowią też element kompozycyjny i tworzą barierę oddzielającą obszar otwartego placu od przestrzeni kawiarnianej i restauracyjnej na parterze. Liczebność lokali gastronomicznych jest duża. Zgodnie z informacją podawaną na stronie internetowej Manufaktury przy placu znajduje się kilkadziesiąt różnych kawiarni, barów i restauracji. 


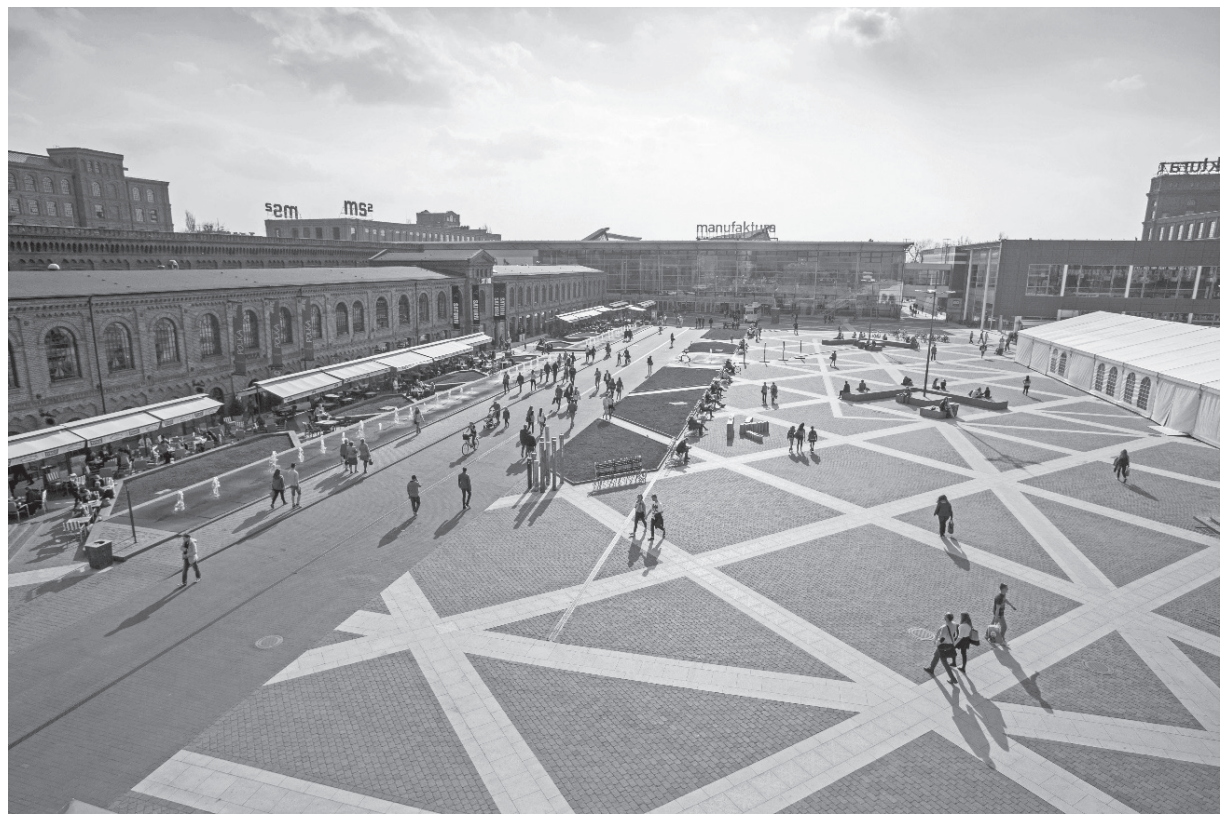

Fot. M. Gałkowski

Zdjęcie 2. Rynek Manufaktury w 2015 roku. Na pierwszy rzut oka nie widać zasadniczych różnic funkcjonalnych w stosunku do innych placów miejskich
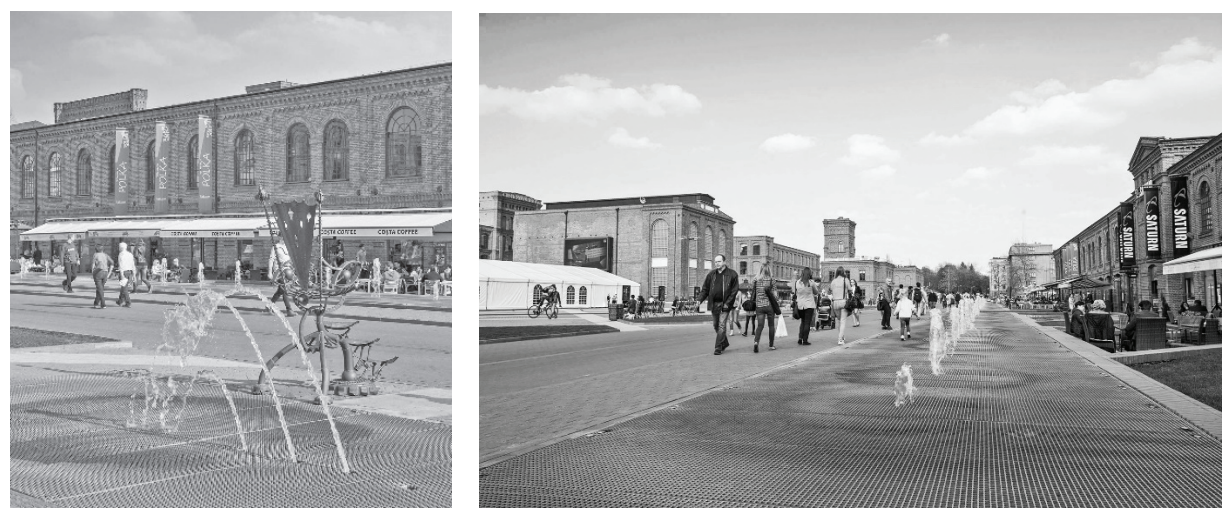

Fot. M. Gałkowski

Zdjęcie 3 i 4 . Hybrydową przestrzeń miejską cechuje wysoka jakość elementów małej architektury 
RYSUNEK 2. Schemat Rynku Manufaktury

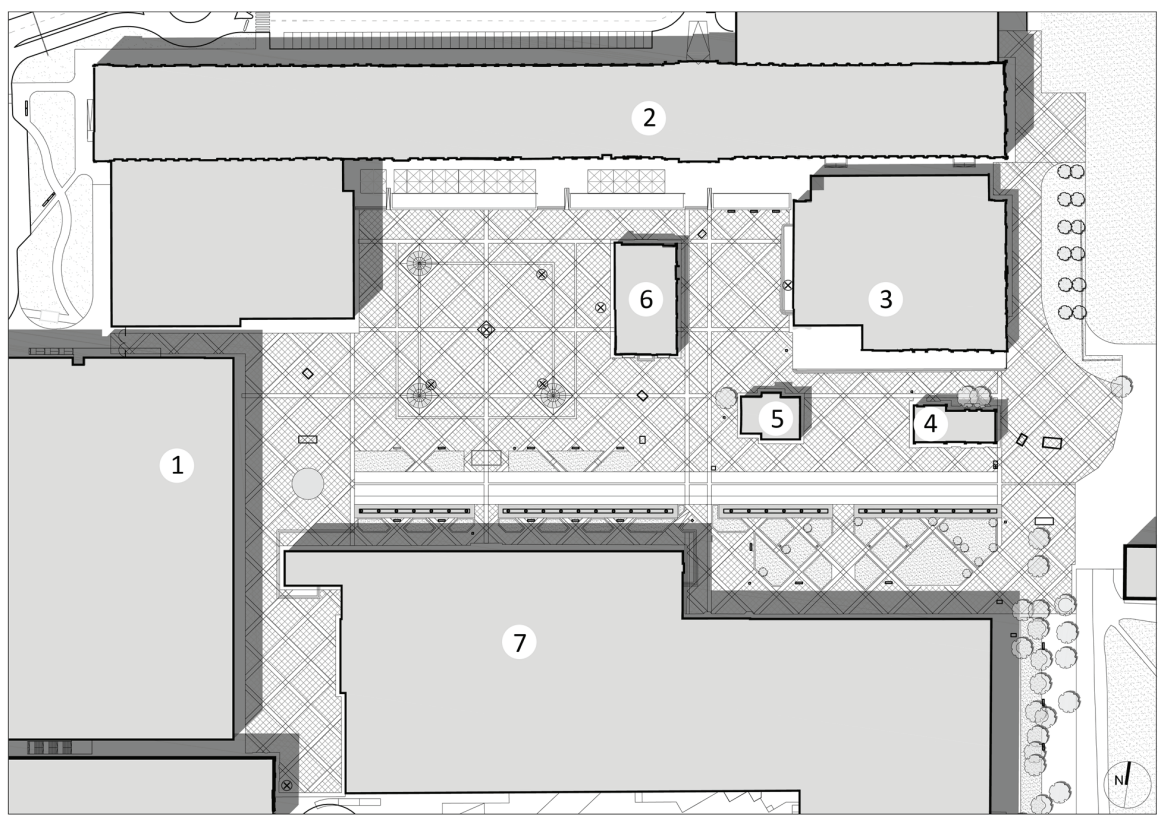

Legenda: 1 - główny budynek galerii handlowej, 2 - handel i usługi (w tym kino i muzeum), 3 - kręgielnia i gastronomia, 4 - gastronomia, 5 - gastronomia, 6 - klub muzyczny, 7 - handel (w tym sklep AGD) i gastronomia

Źródło: opracowanie własne na podstawie materiałów Google Earth i prasowych [Gałkowski 2015].

Plac tętni życiem, zwłaszcza latem. Często organizowane są „wydarzenia" - w postaci koncertów muzycznych czy pokazów mody. W przesłanym w maju 2015 roku komunikacie ${ }^{8}$ biuro $\mathrm{CH}$ Manufaktura tak opisuje rodzaje imprez odbywających się na otwartej przestrzeni rynku:

Przez 9 lat istnienia Manufaktury zorganizowano tu tysiące imprez różnego typu: rozrywkowych, sportowych, kulturalnych. Do największych w ostatnich latach można zaliczyć coroczne urodziny, w ramach których organizowaliśmy koncerty plenerowe, a także spektakle i wielkie widowiska teatrów ulicznych (m.in. Plasticiens Volants, The Dream Engine, Klinika Lalek). Od kilku lat odbywają się koncerty letnie z największymi rozgłośniami radiowymi, podczas których występują topowe polskie gwiazdy. Gościliśmy u siebie takich twórców jak Kayah, Edyta Górniak, Wilki, Kult, Afromental, Ewa Farna czy Mezo. Cykliczną imprezą są letnie koncerty jazzowe w ramach festiwalu „Manu Summer Jazz Sundays”. Ponadto w ramach plaży odbywają się tu turnieje siatkówki plażowej o randze ogólnopolskiej, a w ramach

8 Informacja przesłana do jednego $\mathrm{z}$ autorów przez biuro prasowe Manufaktury w dniu 7 maja 2015 roku, podpisana przez panią Agnieszkę Danowską (e-mail; w zbiorach autorów). 
lodowiska - pokazy jazdy figurowej i lekcje łyżwiarstwa. W trakcie Euro 2012 mieliśmy na rynku ogromną strefę kibica, gdzie tysiące łodzian oglądało zmagania piłkarzy reprezentacji Polski, i nie tylko. Co roku organizujemy też łódzki finał WOŚP. [...] W Manufakturze dzieją się również inne akcje, np. informacyjne (Piknik Funduszy Europejskich - jak pozyskiwać środki z EU), zdrowotne (zbiórka krwi, mammobus, dzień z pielęgniarką i położną, rekord Guinnessa w pomiarze ciśnienia), a także wystawy fotograficzne - w rotundzie i na rynku.

Cytowany opis zdarzeń świadczy o wyjątkowości Manufaktury, bowiem niewiele jest przestrzeni miejskich, w których tak licznie odbywają się wydarzenia kulturalne, sportowe i prospołeczne. Odwołując się do pojęcia dobra wspólnego w ujęciu opisywanym przez Davida Harveya [2012], można wnioskować, że przestrzeń Manufaktury generuje bardzo wiele dobra wspólnego dla społeczności Łodzi. W rzeczy samej, na pierwszy rzut oka wydaje się udaną, dobrze zaprojektowaną i działająca przestrzenią publiczną miasta. Doceniając wszystkie zalety, warto jednak przyjrzeć się funkcjom tej przestrzeni, jej etiologii oraz zjawiskom w niej występującym. Rynek Manufaktury jest w rzeczywistości przestrzenią prywatną, przedłużeniem obszaru najmu centrum handlowego. Potwierdza to zapisana w regulaminie informacja, że do $95 \%$ powierzchni placu może zostać wynajęte prywatnym najemcom na cele czysto komercyjne.

Podobnie jak w przypadku wspomnianych uprzednio przestrzeni BID także tutaj występują zjawiska estetyzacji, czyszczenia i ograniczania aktywności użytkowników. Wszystkie organizowane w tym miejscu wydarzenia mają kilka płaszczyzn znaczeniowych. Służą mieszkańcom, ale są też przeprowadzane w celach marketingowych, gdyż budują pozytywny obraz centrum handlowego jako miejsca oferującego wiele przyjemnych wydarzeń i doznań. Dotyczy to także muzeów, których na terenie Manufaktury zlokalizowano aż trzy (największym jest wspomniane muzeum „ms2”). Oficjalnie instytucje kultury i upamiętnienia są wspierane i promowane przez operatora centrum handlowego. Jednak jak pisze M. Saryusz-Wolska, działania te w rzeczywistości mają inny charakter:

[...] opierając się na sąsiedztwie z innymi muzeami [chodzi o państwowe „ms2”- przyp. M.G., P.A.] oraz na własnych placówkach kulturalnych, Manufaktura wykorzystuje je w znacznie większym stopniu do promocji przez kulturę niż do promocji kultury [2010].

Różnorodne „wydarzenia” mają uprzyjemnić odwiedzającym późniejszy pobyt w galerii handlowej i konsumpcję, która stanowi główny cel. Jak bowiem pisał George Ritzer:

Konsumpcja ma coraz mniej wspólnego z uzyskiwaniem towarów i usług, a coraz więcej z rozrywką. Środki konsumpcji coraz częściej czerpią z doświadczeń przemysłu rozrywkowego i coraz częściej stają się jego elementem [Ritzer 2001: 313]. 
Konsumpcja to przecież nie tylko zakupy w sklepach, ale też usługi. Tę powszechną obecnie strategię polegającą na łączeniu handlu z rozrywką i zabawą Ritzer określa jako retailtainment i wyjaśnia w następujący sposób:

Rosnąca potrzeba organizowania ferii w handlu detalicznym bywa nazywana „detrozrywką” (retailtainment), czyli „rozrywkową sprzedażą detaliczną”, i polega na zwracaniu uwagi klientów na towar i wywoływaniu w nich ochoty do kupna - za pomocą nastroju, emocji, dźwięku i działań [Ritzer 2001: 191].

Należy podkreślić, że prywatni właściciele sąjedynymi reżyserami sytuacji i mają pełną kontrolę nad spektaklem odbywającym się w tej przestrzeni. Dla odwiedzających Manufakturę przewidziano jedynie rolę konsumentów towarów i usług, nie pozostawiając miejsca na działania mogące zaburzyć ten rytuał. Wykluczono też jakąkolwiek spontaniczność czy kontrowersyjność zachowań uczestników, z czego - jak możemy przypuszczać - zdają sobie oni sprawę?.

Co jednak najważniejsze, $\mathrm{w}$ tej przestrzeni nie ma też miejsca na dyskurs polityczny czy światopoglądowy. Jasno mówi o tym poniższy fragment Podręcznika najemcy CH Manufaktura ${ }^{10}$ :

Zakazane jest także prowadzenie działalności sprzecznej z porządkiem publicznym, organizowanie lub zezwalanie na manifestacje i zgromadzenia o charakterze politycznym, wyznaniowym bądź związkowym na terenie Centrum, poza przewidzianymi do tego celu lokalami. Każdy użytkownik jest zobowiązany do uzyskania zezwoleń niezbędnych do prowadzenia działalności.

Oczyszczenie terenów otwartych Manufaktury z działań o charakterze politycznym czy obywatelskim potwierdza też biuro prasowe ${ }^{11}$ :

Manufaktura jest miejscem areligijnym i apolitycznym i tak jest od początku jej działania. Nie można prowadzić tu działalności politycznej ani religijnej.

Ograniczenie swobód obywatelskich nie jest widoczne na pierwszy rzut oka, dlatego bywa pomijane przez wielu autorów, którzy w samych superlatywach piszą o zagadnieniach kompozycji czy architektury przestrzeni takich jak Rynek Manufaktury. Kwestia ta ma jednak kluczowe znaczenie dla społecznej funkcji tego obszaru (i jemu podobnych) w mieście. W przeciwieństwie do powierzchni należących do władz miejskich i zarządzanych przez nie na mocy prawa państwo-

9 M. Saryusz-Wolska [2010] przeprowadziła ciekawy eksperyment: poprosiła przebywających w przestrzeni Rynku Manufaktury o zaśpiewanie z nią, przy akompaniamencie gitary, kilku piosenek. Nie znalazła jednak ochotników - przechodnie obawiali się interwencji ochrony.

10 Podręcznik ten nie jest dostępny publicznie. Autorzy dysponują jego kopią, jednak nie udało się potwierdzić, czy ta wersja dokumentu nadal obowiązuje).

${ }_{11}$ Cytat ze wspomnianego e-maila przesłanego przez biuro prasowe Manufaktury w dniu 7 maja 2015 roku, podpisanego przez panią Agnieszkę Danowską (w zbiorach autorów). 
wego i konstytucji (jak choćby łódzka ulica Piotrkowska) przestrzeń związana z centrum handlowym, jako wyłączona z życia społecznego i politycznego miasta, jest „ułomna”. Celne podsumowanie problemu strategii centrów handlowych mogą stanowić słowa Grzegorza Makowskiego [2003: 134]: ,tak dużo konsumpcji, ile można, i tak dużo życia publicznego, ile potrzeba”.

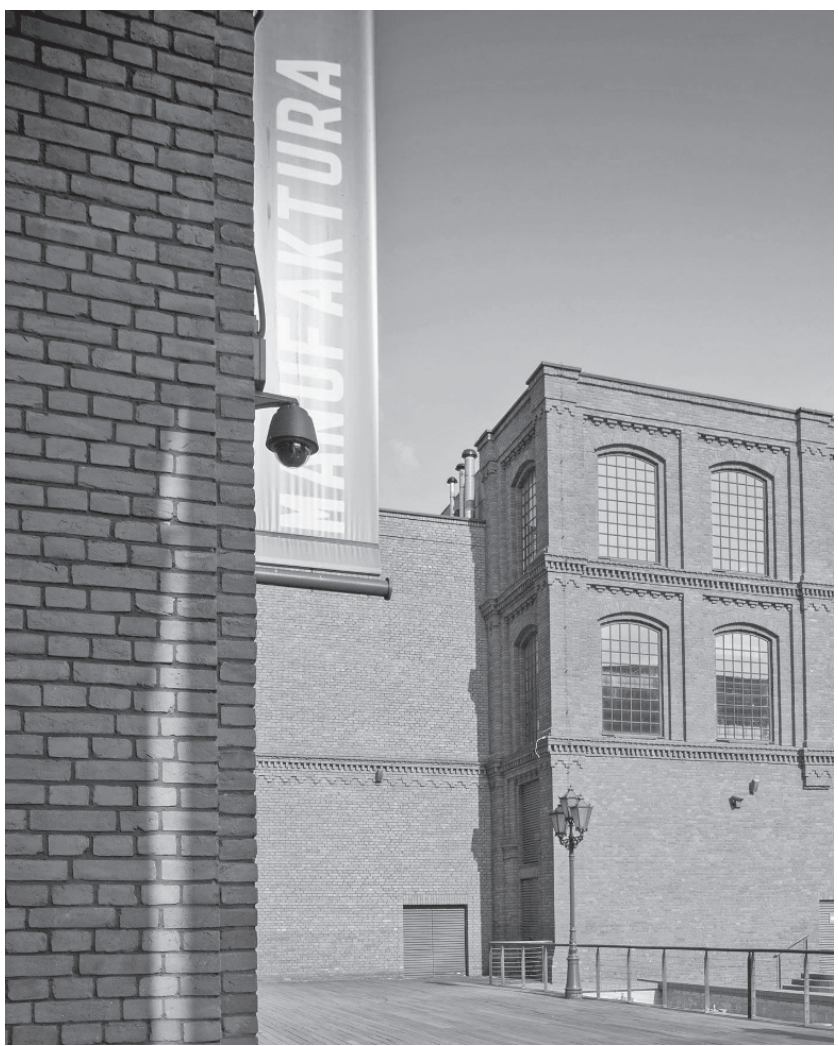

Fot. M. Gałkowski

Zdjęcie 5. Kamery obsługiwane przez prywatne firmy ochroniarskie stale monitorują przestrzeń placu, nadając mu cechy jittery space - według określenia Stevena Flusty’ego [Flusty 1963]

Prywatny obszar rynku Manufaktury jest ściśle kontrolowany, wpięty w system monitoringu centrum handlowego i obsługiwany przez firmy ochroniarskie. Jak pisze Ritzer, „w nowych środkach konsumpcji możliwość sterowania klientami łączy się nierozerwalnie z ich śledzeniem" [Ritzer 2001: 158]. 
Kamery są wszechobecne i służą z jednej strony do zapewnienia bezpieczeństwa, z drugiej zaś także do selekcji użytkowników tej przestrzeni, która jest niejako „oczyszczona” z gości zagrażających realizacji konkretnego scenariusza - bezdomnych, ubogich, a także, sądząc z oficjalnie przekazanej informacji - aktywistów politycznych czy religijnych. Osoby takie są wypraszane poza przestrzeń należącą do Manufaktury ${ }^{12}$. Obserwacja potwierdza tezę, że: „Prywatyzacja przestrzeni publicznych wyklucza lub marginalizuje udział w nich niższych warstw społecznych. Równocześnie ułatwia «militaryzację» przestrzeni”" [Bierwiaczonek, Lewicka, Nawrocki 2012].

Zabytkowa przestrzeń byłych zakładów Izraela Poznańskiego została poddana komodyfikacji, wyczyszczona z prawdziwych znaczeń i realnych społecznych problemów. Fabryczne hale, świadectwo historii miasta i miejsca, wykorzystano jako motyw przewodni - stały się tematem $\left(\right.$ theme $\left.^{13}\right)$ galerii handlowej, dekoracją spektaklu. Otwarta przestrzeń stworzona od podstaw pomiędzy fabrycznymi zabudowaniami to symulacja prawdziwego miejskiego placu z nieustającą feerią wydarzeń i scenariuszy przygotowywanych na potrzeby marketingu, którą „umagicznia" prawdziwa historia, nie nadając jej jednak rzeczywistego znaczenia ${ }^{14}$. Pozory i blichtr zastapiły zarówno dyskurs społeczny, jak i wszelką oddolną aktywność. Spektakl jest w pełni kontrolowany przez właściciela, a jego uczestnicy i aktorzy są stale obserwowani przez kamery i filtrowani przez ochronę $e^{15}$.

\section{NIEJEDNOZNACZNA OCENA PRZESTRZENI PUBLICZNYCH ZARZĄDZANYCH PRZEZ PODMIOTY PRYWATNE - DYSKUSJA}

Sam status własnościowy terenu nie determinuje jego funkcji w mieście i klasyfikacji jako przestrzeni publicznej. Mimo wielu ważnych ułomności funkcjonalnych nie można negować zalet Rynku Manufaktury dla miasta Łodzi (wspomniany wcześniej Bryant Park po rewitalizacji i przekształceniu w BID

12 Warto przy okazji zwrócić uwagę, że osoby te, jeśli nie złamią prawa polskiego, są wypraszane w przestrzeń publiczną należącą do miasta, gdzie ich przebywanie jest legitymizowane polskim prawem państwowym. Autor niniejszego tekstu był świadkiem jednej z takich sytuacji podczas zwiedzania Manufaktury: ochrona bez zbędnych formalności wyprowadziła osobę „wyglądającą na bezdomną" poza granice własności, na publiczny chodnik. [2001].

13 Zjawisko tematyzacji w warunkach amerykańskich opisuje w swej książce Gottdiener

14 O czym wspominał już M. Gałkowski w swej rozprawie doktorskiej [Gałkowski 2015]

15 Steven Flusty [1963] stworzył klasyfikację przestrzeni ze względu na strategie wykluczenia. Można uznać, że rynek, tak zwany Rynek Manufaktury, zalicza się do kategorii prickly space (kolczaste przestrzenie) i jittery space (drżące przestrzenie). 
również wnosi wiele dobrego dla mieszkańców Nowego Jorku $\left.{ }^{16}\right)$. Mimo że motywem wszystkich działań prywatnych właścicieli jest chęć pomnożenia zysków i - nawiązując do tekstów Harveya [2012] - przywłaszczenie renty monopolowej wynikającej z posiadania unikatowego dobra, jakim jest zabytkowa łódzka fabryka, to jednak ich działania przynoszą też pozytywne skutki, przyczyniając się do poszerzania dostępności dóbr kultury dla lokalnej społeczności. Wartością nie do przecenienia jest też sama rewitalizacja zabytkowych budynków fabryki Poznańskiego z zachowaniem choć części ducha tego miejsca oraz stworzenie w jego centrum wysokiej jakości otwartej, pieszej przestrzeni miejskiej o dużych walorach estetycznych, która w krótkim czasie stała się miejscem spotkań mieszkańców Łodzi.

Wprawdzie możemy tu mówić głównie o użytkownikach przestrzeni z grupy dobrze zarabiającej klasy średniej i wyższej (celowo wybranej przez właściciela), jednak mając w pamięci fakt, że cały ten obszar był całkowicie zdewastowany przed wejściem kapitału prywatnego, jego przekształcenie należy uznać za wydarzenie pozytywne.

Analizując przestrzeń Rynku Manufaktury, należy stwierdzić, że ograniczenia w dostępie egzekwowane przez prywatnych ochroniarzy, celowa eliminacja działalności politycznej i sterowanie wszelką aktywnością na terenie placu wskazują na znaczne ograniczenia funkcjonalne i nie pozwalają na zaliczenie tego obszaru do przestrzeni publicznych ${ }^{17}$. Z drugiej strony plac jest licznie użytkowany i pozytywnie odbierany przez mieszkańców Łodzi jako przykład coraz popularniejszej w miastach naszego kręgu kulturowego przestrzeni hybrydowej [Kohn 2010]. Sylke Nissen [2008] stworzyła bardzo pomocny diagram obrazujący rozwój przestrzeni hybrydowej w odniesieniu do prywatyzacji:

16 Choć jednocześnie przynosi też wymierne korzyści prywatnej korporacji; ceny nieruchomości wokół tego parku wzrosły o rekordowe $63 \%$ zgodnie z cytowanym wcześniej raportem CBRE Premiums on the Parks, https://pl.scribd.com/document/104343327/Premiums-on-the-Park-FINAL [dostęp: 30.11.2017]

17 Jeśli odwołamy się do najtrafniejszej, według autorów artykułu, polskiej definicji przestrzeni publicznej pochodzącej z pracy Piotra Lorensa: „Przestrzenią publiczną nazywać więc będziemy ten fragment przestrzeni miejskiej, który - poprzez sposób swojego urządzenia oraz lokalizację w strukturze urbanistycznej - jest przeznaczony na potrzeby realizacji bezpośrednich kontaktów pomiędzy uczestnikami życia społecznego oraz na inne potrzeby społeczne korzystających z niego zbiorowości, pozostając jednocześnie fizycznie dostępnym dla wszystkich zainteresowanych osób. Fizyczna dostępność przestrzeni może być ograniczana czasowo z uwagi na kwestie bezpieczeństwa bądź sposób organizacji jej wykorzystania” [Lorens, Martyniuk-Pęczek 2010: 10]. 
1 Przekształcanie przestrzeni publicznej poprzez prywatne zarządzanie, instalacja znaków mających prywatny charakter, symboliczne wykluczenie poprzez prywatne oznakowanie

2 Semiprywatyzacja przestrzeni publicznej poprzez przebudowę parków i przeniesienie praw użytkowania i zarządzania na podmioty prywatne, czasowe wykluczenie poprzez wprowadzenie wyznaczonych godzin otwarcia

3 Budowa przestrzeni prywatnych z ograniczoną funkcją publiczną, wykluczenie poprzez oznakowanie oraz prywatne siły ochrony

4 Pełna prywatyzacja poprzez sprzedaż quasi-publicznego mienia; wykluczenie poprzez znaki i prywatne siły ochrony

5 Pełna prywatyzacja poprzez sprzedaż nieruchomości publicznych; dostęp ograniczany do klientów /konsumentów/; kontrola przez prywatne siły ochrony

6 Pełna prywatyzacja poprzez sprzedaż nieruchomości publicznych oraz polityczny i administracyjny spin-off miejskich społeczności; pełna kontrola dostępu
Obszary piesze,

Buisness Improvement

Districts (BID)

Przebudowy

i rewitalizacje parków i publicznych obszarów zielonych

Place i skwery przed wejściami do biurowców i prywatnych budynków

Przekształcenia dworców kolejowych w galerie handlowe

Sprzedaż lokalnych nieruchomości i stawianie w ich miejscu centrów handlowych

Osiedla grodzone

Według powyższego diagramu rynek Manufaktury możemy zaliczyć do stadium piątego, co potwierdza hybrydowy charakter tej przestrzeni.

Takie hybrydowe obszary miasta nie mogą być traktowane jako prawdziwie publiczne, ani nie pełnią takiej funkcji w mieście. Z pewnością jednak uzupełniają braki w warstwie kultury masowej oraz tworzą znakomite obszary służące socjalizacji (a to socjalizacja, z punktu widzenia użytkowników, jest obecnie najistotniejszą bodaj funkcją dzisiejszych miejskich pieszych przestrzeni).

\section{PODSUMOWANIE I WSKAZANIA DO DALSZYCH BADAŃ}

Przestrzeń miasta nigdy nie była w pełni dostępna, co potwierdza już archetypiczny przypadek greckiej agory, na której wyraźnie uwidaczniała się dominacja pewnych grup społecznych i wykluczanie innych. Wartościowe jest jednak dążenie do zagwarantowania maksymalnego dostępu do przestrzeni publicznych [Kohn 2004; Lofland 2007] i zapewnienia w nich pełnej swobody działania opartej na prawach podstawowych (konstytucyjnych). W mieście powinna bowiem istnieć przestrzeń prawdziwie publiczna, będąca dobrem wspólnym społeczności, 
która w jak największym stopniu umożliwia realizację pełnego spektrum działań społecznych, religijnych i politycznych (w tym działań wyrażających społeczny sprzeciw, jak demonstracje, pikiety czy wiece) [Gałkowski 2015].

We współczesnych miastach, w których granice obszarów prywatnych i publicznych zaczynają na siebie zachodzić i w których rośnie liczba przestrzeni hybrydowych łączących cechy charakterystyczne dla obszarów publicznych i prywatnych, istnieją uzasadnione potrzeby (1) monitorowania ich liczby i powierzchni, a także (2) badania zmian funkcjonalnych, które towarzyszą ich powstawaniu. Te ostatnie są kluczowe dla pogłębienia tematyki wykluczenia społecznego, gdyż arbitralnie tworzone, prywatne regulaminy de facto nie pozwalają na udział w społeczeństwie konkretnym grupom osób. Niestety w obecnym momencie nie mamy dokładnej wiedzy o tym, które grupy są wykluczane, bowiem regulaminy te nie są często w ogóle upubliczniane. Ważne jest również rozumienie społecznego odbioru obszarów hybrydowych.

Metodologie badań funkcji przestrzeni publicznej są skomplikowane ze względu na złożoną naturę otwartej przestrzeni miejskiej, wielość jej funkcji i kształtów. Satysfakcjonujące opisowe badanie funkcjonalności przestrzeni można uzyskać metodą analizy przypadków. Jednakże metoda ta ma zasadnicze ograniczenia dotyczące konstruowania wyjaśnień zjawisk, tzn. wskazywania konkretnych przyczyn zachodzących zjawisk. W takiej sytuacji można wspomagać się technikami porównawczymi (ang. comparative case studies), zadowalające porównanie jest jednak trudne $\mathrm{z}$ tego względu, że przestrzenie hybrydowe często różnią się strukturą, funkcjami oraz specyficznym kontekstem lokalnym.

Najbardziej kompleksową metodologię sprawdzania, ,jak bardzo publiczna jest przestrzeń publiczna”, opisała Georgiana Varna [2014]. Metodologia ta została zbudowana w oparciu o tzw. ,model gwiazdy” - badanie i walidację pięciu wybranych obszarów funkcjonalnych: obywatelskości (civility), animacji (animation), konfiguracji fizycznej (physical configuration), własności (ownership) i kontroli (control). Z uwagi na ścisłe ramy obserwacji i jasne wytyczne daje możliwość uniwersalnego porównania przestrzeni o różnej morfologii i historii. Wartościowym uzupełnieniem „modelu gwiazdy” mogą okazać się badania kwestionariuszowe użytkowników przestrzeni miejskiej, które wskażą, w jaki sposób odbierają oni otaczającą ich rzeczywistość przestrzenną, oraz jak dalece są świadomi ograniczeń występujących w obszarach hybrydowych. Autorzy opracowali ramy metodologiczne dla pilotażowych badań hybrydowych przestrzeni miejskich. Propozycja badań w duchu mixed-methods opiera się na połączeniu wybranych wskaźników wskazanych w „modelu gwiazdy”, których wartości w większości można określić obserwacyjnie, oraz wskaźników wybranych wymiarów zawartych w koncepcji 
Lyn Lofland [2007], których wartości będą mierzone za pomocą kwestionariusza ankiety wypełnianego przez użytkowników przestrzeni hybrydowej. Dla lepszego zrozumienia otrzymanych wartości wyników oraz zidentyfikowania kontekstu funkcjonowania danej przestrzeni hybrydowej obserwacja oraz badanie kwestionariuszowe zostaną uzupełnione serią zogniskowanych wywiadów grupowych. Autorzy są przekonani, że zastosowanie tej metody okaże się przydatne nie tylko jako narzędzie kompleksowego opisu funkcji i odbioru przestrzeni hybrydowych, ale także zaowocuje w podejściu comparative case studies, gdyż umożliwi pełniejsze porównanie istniejących przestrzeni hybrydowych.

\section{BIBLIOGRAFIA}

Bauman Zygmunt. 2006. Praca Konsumpcjonizm i Nowi Ubodzy. Kraków: Wydawnictwo WAM.

Bierwiaczonek Krzysztof, Barbara Lewicka, Tomasz Nawrocki. 2012. Rynki, Malle i Cmentarze. Kraków: Zakład Wydawniczy Nomos.

Debord Guy. 2006. Społeczeństwo spektaklu oraz Rozważania o społeczeństwie spektaklu. Warszawa: Państwowy Instytut Wydawniczy.

Flusty Steven. 1963. Building paranoia: The proliferation of intardictory space and the erosion of spatial justice. Los Angeles Forum for Architecture and Urban Design.

Gałkowski Marcin. 2015. Zmiany funkcjonalne miejskich pieszych przestrzeni publicznych w procesach komodyfikacji i prywatyzacji. Rozprawa doktorska (niepublikowana). Politechnika Krakowska.

Gądecki Jacek. 2009. Za Murami. Osiedla grodzone w Polsce - analiza dyskursu. Wrocław: Wydawnictwo Uniwersytetu Wrocławskiego.

Gehl Jan. 2010. Cities for people. Washington: Island Press.

Gehl Jan. 2006. New city life. Kopenhaga: The Danish Architectural Press.

Gehl Jan, Lars Gemzøe. 2004. Public Spaces, Public Life. Kopenhaga: Danish Architectural Press.

Gehl Jan, Lars Gemzøe. 2000. New City Spaces. Kopenhaga: The Danish Architectural Press.

Gottdiener Mark. 2001. The Theming of America. American dreams, media fantasies, and themed enviroment. Boulder: Westview Press.

Habermas Jürgen. 2007. Strukturalne przeobrażenia sfery publicznej. Warszawa: Wydawnictwo Naukowe PWN.

Harvey David. 2012. Bunt Miast. Prawo do miasta i miejska rewolucja. Warszawa: Fundacja Kultury Bęc Zmiana.

Harvey David. 2008. Neoliberalizm. Historia katastrofy. Warszawa: Instytut Wydawniczy Książka i Prasa.

Jacobs Jane. 1961. The death and life of great American cities. Nowy Jork: Random House.

Jałowiecki Bohdan. 2010. Spoleczne wytwarzanie przestrzeni. Warszawa: Wydawnictwo Naukowe SCHOLAR.

Kayden Jerold S. 2011. Zuccotti Park and the Private Plaza Problem.

The New York Times. http://nyti.ms/1Pi6jaN [dostęp: 19.10.2015]. 
Kohn Margaret. 2004. Brave new neighborhoods. The privatization of public space. New York and London: Routledge.

Lofland Lyn H. 2007. The public realm. Exploring the city's quintessential social territory. Londyn: Aladine Transaction.

Lorens Piotr, Justyna Martyniuk-Pęczek. 2010. Problemy ksztaltowania przestrzeni publicznych. Gdańsk: Wydawnictwo Urbanista.

Low Setha. 2003. Behind the gates. Life, Security and Pursuit of Hapiness in Fortress America. New York: Routledge.

Makowski Grzegorz. 2003. Światynia Konsumpcji. Geneza i znaczenie Centrum Handlowego. Warszawa: Wydawnictwo TRIO.

Mitchell Don, Lynn A. Staeheli. 2008. The people's property? Power, politics and the public. Abingdon: Routeledge.

Mitchell Don. 2003. The right to the city. Social justice and the fight for public space. Londyn: The Guilford Press.

Moskowitz Peter. 2017. How to kill a city. Gentrification, ineqality, and the fight for the neighborohood. Nation Books

Murray Michael. 2010. „Private management of public spaces: nonprofit organizations and urban parks" Harvard Environmental Law Review 34: 180-203.

Nissen Sylke. 2008. „Urban transformation from public and private space to spaces of hybrid character". Czech Sociological Review 44, 06: 1129-1149.

Oldenburg Ray. 1989. The great good place: cafes, coffee shops, bookstores, bars, hair salons, and other hangouts at the heart of a community. New York: Parragon Books.

Orum Anthony M., Zachary P. Neal. 2010. Common ground? Readings and reflections on public space. New York: Routeledge.

Pluciński Przemysław, Marek Nowak. (red.). 2011. O miejskiej Sferze Publicznej. Obywatelskość i konflikty o przestrzeń. Kraków: korporacja ha!art.

Rąkowska Katarzyna. 2009. Manufaktura, czyli symbol udanej rewitalizacji.

Inżynier budownictwa. http://www.inzynierbudownictwa.pl/biznes,inwestycje, artykul,manufaktura_czyli_symbol_udanej_rewitalizacji, 3314 [data dostępu: 2018.06.30].

Ritzer George. 2001. Magiczny świat konsumpcji. Warszawa: Muza SA.

Saryusz-Wolska Magdalena. 2010. Łódzka Manufaktura - przemiany przestrzeni publicznej i muzealnej. W: Sztuka - kapitat kulturowy polskich miast. E. Rewers, A. Skórzyńska (red.). 103-120 Poznań: Uniwersytet im. Adama Mickiewicza w Poznaniu.

Shiffman Ron. (red.). 2012. Zuccotti Park. Freedom of assembly and the occupation of public space. Oakland: New Village Press.

Sorkin Michael. (red.). 1992. Variations on a Theme Park. The new american city and the end of public space. New York: Hill and Wang.

Zukin Sharon. 1996. The cultures of cities. New York: Wiley-Blackwell Publishers.

Varna Georgiana. 2014. Measuring public space: the star model. Farnham: Ashgate Publishing Limited. 
Marcin Gatkowski

Patrycja Antosz

\title{
PRIVATELY OWNED PUBLIC SPACES (HYBRID PUBLIC SPACES) AND THEIR FUNCTION WITHIN THE CITY
}

\begin{abstract}
The purpose of this paper is to allow for a better understanding of the specificity of hybrid spaces present in cities. The number of these particular city spaces is increasing, as the model of social relationships based on consumption becomes dominant [Bauman 2006; Ritzer 2001]. As a result of these changes, urban spaces, including pedestrian open spaces, are becoming a commodity used for the accumulation and reproduction of capital. The pressure of private capital quickly leads to the creation of a new type of city space that is an amalgamation of features found in private and public spaces. Several authors have labelled them hybrid spaces [Kohn 2004; Nissen 2008]. These areas can still be used for socializing, but commodification has strongly changed their function, compared to the traditionally understood idea of a public space. The commodification process usually leads to the homogenization of city spaces, both functionally and visually. The result is the formation of areas of the city dominated by entertainment, in which users are segregated, and the scenario of their possible actions is predetermined. What is more, there is also a limitation of any civic activities [Harvey 2012; Kohn 2004; Lofland 2007; Low, Smith 2006; Mitchell 2003; Sorkin, 1992]. The commodified space does not support deeper social functions: from unbalanced, natural encounters with "others" and "strangers", through public gatherings, to the expression of civic protests. These processes usually also lead to the homogenization of inner-city spaces, both in the visual and functional layers. These limitations and the reduction of physical access to hybrid urban areas can become a source of serious social conflicts.

To better describe the issues outlined above, the privatized pedestrian space of the "Manufaktura" shopping center in Lodz (Central Poland) is analysed. This retail complex consists of several buildings, which are located around a privately-owned square, which (according to some sources) is the largest private city plaza in Europe. The discussion about the functions of this area as a hybrid space leads to the conclusion that a methodology of systematic description, which also allows for comparisons between such spaces (at the functional layer), is lacking. Therefore, the authors outline a mixed-methods approach which fills the existing gap.
\end{abstract}

Keywords: city, public space, privatization of public space, commodification, right to the city, functions of public space, urban space, transformations of urban space, hybrid public spaces, POPS 